\title{
Erratum to: Multilocus phylogeography and phylogenetics using sequence-based markers
}

Patrícia H. Brito $\cdot$ Scott V. Edwards

Published online: 4 March 2010

(C) Springer Science+Business Media B.V. 2010

Erratum to: Genetica (2009) 135:439-455

DOI 10.1007/s10709-008-9293-3

This article was intended for publication in the Special Issue of Ecological Genomics.
An error of classification during peer review process has prevented its inclusion in this special issue, as it has been published earlier in Volume 135, Number 3.

The online version of the original article can be found under doi: 10.1007/s10709-008-9293-3.

P. H. Brito $\cdot$ S. V. Edwards $(\bowtie)$

Department of Organismic and Evolutionary Biology, Harvard

University, 26 Oxford Street, Cambridge, MA 02138, USA

e-mail: sedwards@fas.harvard.edu

P. H. Brito

Instituto Gulbenkian de Ciência, Rua Quinta Grande, 6,

Apartado 14, Oeiras 2781-901, Portugal

e-mail: pbrito@oeb.harvard.edu 